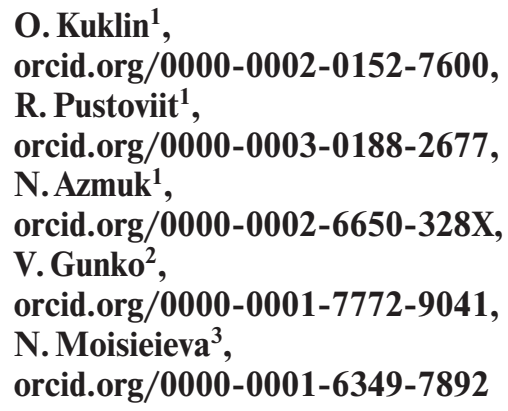

1 - Cherkasy State Business-College, Cherkasy, Ukraine, e-mail: rfpustovit@gmail.com

2 - Cherkasy Gymnasium No. 9, Cherkasy, Ukraine

3 - Petro Vasylenko Kharkiv National Technical University of Agriculture, Kharkiv, Ukraine

\title{
INSTITUTIONAL AND SOCIO-ECONOMIC FACTORS OF THE EDUCATIONAL TREND IN UKRAINE IN THE CONTEXT OF EUROPEAN INTEGRATION
}

Purpose. To assess institutional factors and the results of education reform in Ukraine, considering economic and social development of the country; to specify the main institutional European integration tendencies of Ukraine in the field of education taking into account the factor of human capital.

Methodology. The methodological basis of the work proposed involves such universal methods of scientific knowledge as analysis; synthesis; inductive method; deductive method; causal modeling; combined application of complementary approaches and methods based on the principles of general scientific methodology, in particular, competency-based, person-centered, culturological ones.

Findings. It is found that the conditions for reforming Ukrainian education taking into account the global educational and European integration trends provide for institutional processes in the socio-economic sphere and radical changes in the content, forms of organization and methods of teaching and education. Namely, this refers to designing the educational process as an institution of successful personal and professional socialization based on EU requirements, which will lead to the growth of national capital through accelerated human accumulation and bring Ukraine closer to complete European integration.

Originality. The study identifies key trends in Ukrainian, European and world educational spheres, as well as the reasons that negatively affect the development of education in Ukraine and do not allow it to significantly influence the competitive potential of countries and deliver on European integration opportunities. In contrast to previously suggested investigations, this approach focuses on the institutional and socio-economic factors of the educational trend.

Practical value. The results of the research can be used by experts in the formation of institutional requirements for designing the trend of the education system in Ukraine, taking into account the requirements of European integration.

Keywords: institutional economy, educational process, human capital, European integration

Introduction. In 1991, after gaining independence, the Ukrainian state had to give the acquired sovereignty a real socio-economic content. As in other post-Soviet countries, the institutions of power began radical institutional reforms after the first democratic elections. At the same time, the key tasks of the institution of education in the process of formation of the statehood of Ukraine were determined by the transformational process of orientation to the democratic and legal state, the establishment of an efficient economy, the need to overcome the country's lagging behind global trends in socio-economic development. We also emphasize that the acceleration of globalization and the formation of post-industrial societies in the European Union, a member of which Ukraine aspires to become, are directly related to qualitative changes in the development of educational institutions.

Therefore, in order to become one of the economically developed countries of the global economy and Europe, in particular, Ukraine must take into account the main global trends of the educational sphere in the formation and improvement of the institution of education. At the same time, we stress on the point that education is one of the most important factors in shaping the new quality of the economy and society as a whole, and overcoming the economic and institutional problems we currently have in Ukraine depends crucially on the direction and efficiency of the educational process. This is exacerbated by the extremely negative consequences for the global economy from the global coronavirus pandemic, which are assessed to be as bad, or even much worse, as the global financial and economic crisis of 20082012. Therefore, education, as one of the crucial factors in

(C) Kuklin O., Pustoviit R., Azmuk N., Gunko V., Moisieieva N., 2021 overcoming the crisis, deserves close attention of the world scientific community.

Literature review. The issues related to the study on factors of the educational macro process in the socio-economic development of the global economy have been considered by scientists who represent, first of all, the economic approach to human behavior, in particular, G. Becker (1962), T. Schultz (1972), S. Kuznets (1973), R. Solow (1974), E. Denison (1985). Velychko and Velychko [1] note that higher educational institutions use an old-fashioned and low-efficient bureaucratic type of management, which was widely spread in the times of the USSR. It reduces the prospects of their integration to the global educational system. Nitsenko, et al. [2] offers to decrease the number of higher educational institutions by creating large regional institutions, which will improve research and education processes and reduce the level of students' uncertainty before submitting documents. Under such circumstances, Burlay [3] suggests carrying out implementation of the Ukrainian and European legislation, increase of social and economic standards of life of the population, including education. The scientific developments by these scientists are focused on the problems of education, science and mentality, as the main factors of growth and development of modern economy, potential for business, improving the quality of life of households.

As for the institutional factors of countries' social and economic development, including the sphere of education, we would like to mention the research data by such prominent institutionalists as: D. North (1990), T. Eggertsson (1990), E. Ostrom (2005), O. Williamson (1985).

Unsolved aspects of the problem. Along with that, some of the important problems of education, as one of the main fac- 
tors in the formation of a new quality of economy and society as a whole need more attention given the systemic nature of their emergence, specific features of socio-economic development, particularly, of Ukraine, and dynamics of current changes in institutional conditions, which previously defined and shaped the common institutions in the global economy. Based on this, the study on trends in the Ukrainian, European and world educational spheres acquires special significance, as well as identification of the reasons that negatively affect the development of education and do not allow it to fully influence the competitive potential of countries and realize Ukraine's European integration potential.

Results. Characteristics of the development and reforming of the educational system in Ukraine within transformation period. Similarly to the post-socialist countries of Eastern Europe, Ukraine has been witnessing significant changes in the field of education in recent decades. They influence institutional philosophy of acquiring knowledge, skills; global goals and objectives; organizational structures; content; approaches to the development of educational standards and curricula; forms and methods for ensuring the quality of education; quality control of education and activities of educational institutions; funding and many other aspects.

The analysis of the content of educational reforms carried out in Ukraine since independence shows that Ukrainian society has tried to modernize the country's innovation opportunities and achieve positive socio-economic results due to the entry into the global world. At the same time, the role of education in the process of formation of Ukraine's statehood was determined by the tasks of its transition to a democratic and legal state, the need to overcome the country's lag behind global trends in economic and social development.

During the years of independence, Ukraine has formed its own state educational policy, established the institutions that develop and implement it, identified the principles and basic institutional mechanisms of policy in the educational area. In 1991, with the adoption of the Law of Ukraine "On Education" and other legislative acts, educational and educationalqualification levels, state standards of education in accordance with the requirements for the content, scope and levels of educational and professional training were approved. Compliance of educational services with state standards and requirements was determined by the established procedure for licensing, inspection, certification and accreditation of educational institutions.

Ukraine's accession to the Bologna Process in 2005 led to the adoption of regulations on the organization of the educational process in higher education, its approximation to European standards, which required significant changes in structure, content, financing and management of education for the integration of the Ukrainian national educational system into the European one.

As for the quantitative indicators for the main components of the Ukrainian educational system such as secondary, vocational and higher education institutions, taking into account demographic crisis, which will be analyzed below, we have the following situation (Figs. 1, 2).

However, it should be admitted that today, Ukrainian educational system, despite its relatively high quantitative indicators, does not fully ensure the growth of the country's competitiveness. In the Global Competitiveness Index 2019, Ukraine took only $85^{\text {th }}$ place out of 141 countries, having lost two positions in a year and moved from $83^{\text {rd }}$ to $85^{\text {th }}$ position. The nearest geographical neighbors of Ukraine took the following places in the rating: Poland $-37^{\text {th }}$, Russia $-43^{\text {rd }}$, Romania $-51^{\text {st }}$, Moldova $-86^{\text {th }}$. Although among the positions of Ukraine in the ranking, we will highlight those related to the educational sphere, namely the coverage indicators: critical thinking in teaching - position 31, student workload per teacher - position 33 , skill of graduates - position 54 , quality of professional training - position 65 , and volume of staff

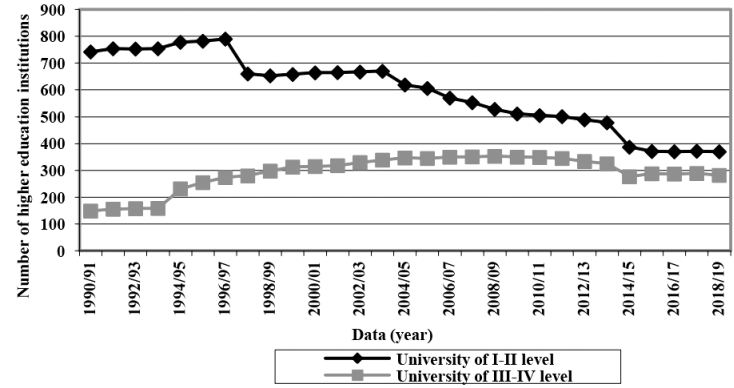

Note. For the years 2014/15-2018/19, the data are presented without taking into account the temporarily occupied territory of the Autonomous Republic of Crimea, the city of Sevastopol and part of the temporarily occupied territories in Donetsk and Luhansk regions

Fig. 1. The number of students in general educational establishments (GEE) and vocational schools (VS), thousand persons [4]

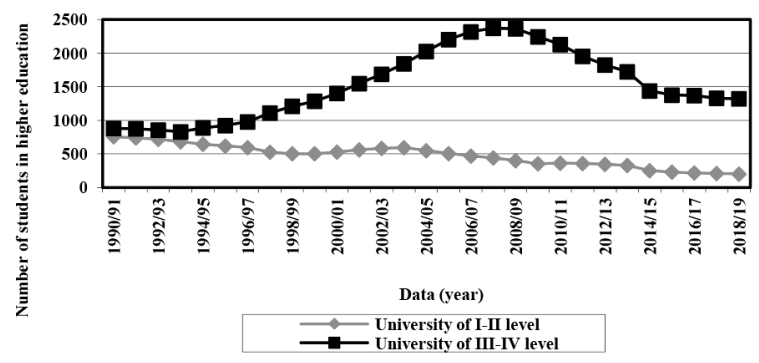

Note. For the years 2014/15-2018/19, the data are presented without taking into account the temporarily occupied territory of the Autonomous Republic of Crimea, the city of Sevastopol and part of the temporarily occupied territories in Donetsk and Luhansk regions

Fig. 2. The number of students in higher educational institutions of I-II (colleges, technical schools) and III-IV (universities, academies, institutes) levels of accreditation, thousand persons

training - position 65 . It is worth noting that according to such an indicator as extent staff training, Ukraine ranked $65^{\text {th }}$, and rose by 30 points over the past few years. In general, according to the skills index, we are at $44^{\text {th }}$ position. Researchers also ranked Ukraine $60^{\text {th }}$ in terms of innovation opportunities [5]. They also referred Ukraine to the group of countries that are moving from the first stage (factor driven - the driver of competitiveness is the production resources) to the second stage (efficiency driven - the economy is focused on increasing efficiency). The third stage - innovation driven, i. e. development through innovation, is still not available for Ukraine.

Given the above, we can conclude that Ukraine loses to other countries not in absolute indices of education, but in the pace of reforms and qualitative characteristics of transformation. It is especially significant that the loss of positions in terms of "quality of training" significantly inhibits the growth of competitiveness of the country's economy. This component belongs to the group of so-called "efficiency enhancers", which are key factors in calculating the index for countries at the second stage of development.

Despite the slight growth of GDP per capita in Ukraine over the past five years, it can be noted that the low level of development of the Ukrainian economy and its competitiveness is also explained by military aggression and destabilizing effects of the Russian leadership, as well as the specific features of economic policy pursued by the government and the $\mathrm{Na}-$ tional Bank of Ukraine.

Well-known Norwegian economist, Professor E. Reinert, believes that a positive example for Ukraine is Ireland, an agrarian country in the past, which in the 80 s of last century 
identified the key task of achieving excellence in information technology. To complete this task, the state has carried out appropriate modernization of education. In addition to this component of economic development, E. Reinert also points to the need for diversified industry, added value in the production process and the need for a qualitative increase in wages [6].

It should be emphasized that the domestic educational system was mostly formed during the Soviet period and mainly in response to the administrative needs of the state, especially in the military-industrial complex (MIC). In order to solve the problems of increasing the country's defense capabilities, creating a nuclear capability, and a space program, it was necessary to start the relevant branches of the economy, which provided for appropriate requirements for specialists. Therefore, higher educational institutions (HEI) were created, taking into account the development plans of the state, and received not only orders for training in certain specialties, but also the necessary resources. As a result, the most powerful institutes and universities were formed in the field of natural sciences. Thus, Soviet universities were focused primarily on the implementation of state tasks of the military-industrial complex, which explains, for example, important basic research in this area, but insufficient level of implementation of developments within branches that directly improve living standards. In the Soviet educational system, the state was the customer, so the list of specialties met the needs of training graduates in accordance with economic policy, especially in the field of military-industrial complex.

With the beginning of market reforms in Ukraine, educational disparities began to manifest themselves strikingly. Thus, in 1990-1991 there were 1246 vocational schools and 149 universities (universities, academies, institutes) in the country, in academic year 2018-2019 their ratio was already 736 to 282 . Accordingly, the number of higher educational institutions has almost doubled. Simultaneously with the fast reduction of enterprises, especially in industry, private universities were established rapidly with an emphasis on legal and economic specialties. Meanwhile, the mass demand for higher education coincided with the needs of public higher educational institutions to increase budget funding. State-owned educational institutions were no longer able to meet the demand for education for all the willing, which led to an uncontrolled increase in the number of private universities with the predictable deterioration in the quality of education. The predominant offer of new educational places, both in private and public universities, was created in the "humanitarian plane" Economics and Law. These specialties did not require large expenditures on material and technical base, in contrast to the technical, and enjoyed growing demand.

At the same time, there is a shortage of specialists in certain professions and a relative surplus of others in the Ukrainian labor market. This is evidenced by the difficulties employers encounter when hiring specialists of the required qualifications, on the one hand, and university graduates when searching job, on the other. The discrepancy between the demand and supply of knowledge and skills in Ukraine is confirmed by the studies that record the shortage of skilled manual labor staff and the relative surplus of "non-productive personnel" of enterprises, organizations and firms. To some extent, this is due to structural disparities in state order, when the gap between the financing of the annual state order for higher and vocational education was growing (Fig. 3, [4]).

We stress the fact that today, education is becoming one of the most important factors in the formation of a new quality of the economy and society, and its modernization is crucial to overcome the socio-economic crisis in Ukraine, solving foreign and domestic political problems and European integration potential. Thus, under modernization of education we understand the process of formation of the ability of the state within in the system of education to do the following: to adapt to dynamic institutional conditions and tasks constantly and

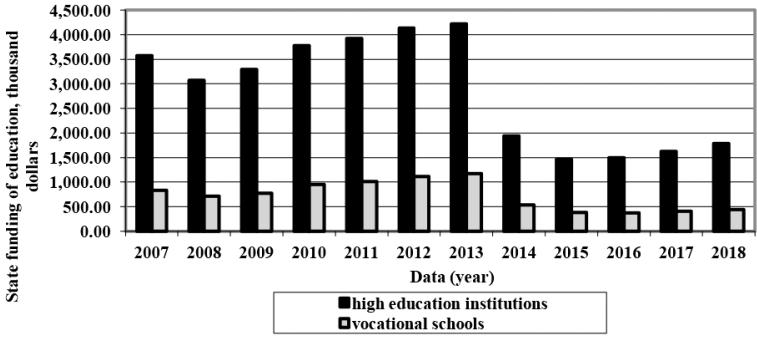

Fig. 3. State funding of higher and vocational education for the period of 2007-2018, thousand dollars

successfully; create new educational institutes; modify the old ormal rules while forming channels for effective dialogue with society, business and state; to develop a new democratic type of interaction of key institutional "players" in the area of education. Therefore, the strategic objectives of modernization of education in Ukraine are the transformation of quantitative indicators of educational services into qualitative ones. However, economic efficiency and competitive advantage can be achieved by means of innovation, which contributes to the emergence of innovative products and technologies [7]. The indicator that captures innovation at the national level is the ranking of countries by the number of patents, trademarks and copyrights - a comparative analysis of statistic data on the activity of countries and world territories on intellectual property. It is the statistics of intellectual property components that are the main indicator of innovation potential and one of the key indicators of economic development of countries and regions. It should be noted that Ukraine ranks $22^{\text {nd }}$ in the global rating of registration for this indicator [8].

The stated is proved by the fact that the increase of the population's level of education forms the institutional environment, which is favourable for the development not only of economy but all fields of human life. Better education (knowledge) leads to innovations at the level of business strategy and practice. At the same time, economic development keeps up with the process of modernization of technologies. Thus, education is one of the key factors of economic development, and its impact on this trend should be assessed considering the cultural factor of social and economic changes, that is emphasized by institutional theory (The Role of Education and Universities in Modernization Processes in Central and SouthEastern European Countries in $19^{\text {th }}$ and $20^{\text {th }}$ Century (2011)/ edited by Peter Vodopivec and Aleš Gabrič - Ljubljana: Institut za novejšo zgodovino).

Priority areas for improving the institutional environment in Ukraine in the context of the European educational vector. The most important component of European integration for Ukraine is real progress in implementing the declared reforms and creating conditions for the formation of an institutional environment in accordance with European standards, which will allow achieving acceptable economic growth and create the necessary conditions for European integration processes. However, despite ongoing reforms, the quality of formal and informal institutions, the problems with the rule of law and corruption have a negative impact on European integration and become increasingly important for European integration processes. The European future to an increasing extent depends on the nature of the institutional changes taking place in Ukraine, and particularly, in the sphere of education.

We also stress that in the institutional environment of the countries where there is no clear specification of property rights, there is excessive bureaucratic administration of entrepreneurial activity, lack of economic and legal system, which prevents discrimination and opportunism by state regulators and minimizes opportunistic transactions costs of economic entities, it will not be possible to achieve stable economic growth. Along with the above, we emphasize that one of the 
most important arguments for economic development is the institutional factors that directly and significantly affect the "rules of the market game", determine the nature of interactions of economic entities and motivate their behavior in the use of resources and assets. At the same time, when studying the institutional environment, such institutional factors that determine the educational and ideological potential of the state deserve special attention, and ultimately create appropriate conditions for the economic development of the country.

In the "third world" countries, most people do not have the opportunity to attend school, and for those who are able to do so, the quality of teaching, methodological and informational support is unsatisfactory. Law level of education in poor countries is a consequence of the functioning of economic institutions, which do not create incentives for parents to send their children to school, and political institutions, in turn, fail to encourage governments to establish and support schools and universities that meet the needs of parents and children. Such states pay a "high price" for the lack of education of their population and the shortage of inclusive education markets. They are unable to mobilize the talents that are emerging in the country.

Unfortunately, the realities of Ukraine have confirmed the fact that the economy, in the absence of a common institutional environment in the EU, is transformed into a multi-institutional structure that only superficially resembles some aspects of a developed social market economy and does not meet the fundamental institutional requirements of developed countries. Under such circumstances, opportunistic behavior during the adoption and implementation of contracts is a consequence of failures in the formation of the institutional environment and the blocking effect, which is the result of dependence on the previous trajectory of the country's development. After all, the limitations that we have today, and which are inherited from the past, along with rules, norms, traditions, hinder further effective socio-economic development and include ideas about functioning in new transformational conditions. At the same time, a number of economic agents, primarily the "bureaucracy of power from the past", are trying to keep the old rules at all costs. Thence, the dependence on the previous trajectory of development is defined as "cultural heritage received as a dowry" (North, 1993).

The above-mentioned European integration institutional ideology is able to explain the negative factors of the process of reforming the institutional environment in Ukraine and the unsatisfactory results of its functioning. Under such conditions, considerable profits for a narrow stratum of a few turn into poverty for the majority of the country's population, when D. Rawls' formulation of the principles of justice for institutions is not implemented. Therefore, institutional changes do not necessarily lead to economic growth, but rather in the interests of those who can bargain for new rules of the "market game" that will lead to their own enrichment. This is due to the fact that political and economic leaders have a diverse and effective set of tools to guide the further socio-economic development of the country, but still for the most part these opportunities encourage redistribution rather than production of material goods and form monopolies rather than competitive environment (North, 1990).

This conclusion is confirmed by the fact that Ukraine took only position 71 in the annual ranking of the World Bank Doing Business 2019, which determines the level of ease of doing business in 190 countries [9] (Table). This records one of the lowest positions among the neighboring countries and states of the former USSR. Worse positions according to this indicator are shown only by Uzbekistan and Tajikistan, and in the top thirty of the overall ranking of post-Soviet countries were included Georgia ( $6^{\text {th }}$ place in the overall ranking), Lithuania (14), Estonia (16), Latvia (19), Azerbaijan (25) and Kazakhstan (28).

At the same time, the institutional feature of Ukraine is its significant differences due to regional factors. This includes, in

\section{Table}

Some Central and Eastern European countries are ranked by the World Bank Doing Business 2019

\begin{tabular}{|c|l|c|c|}
\hline Position & \multicolumn{1}{|c|}{ Country } & $\begin{array}{c}\text { Number } \\
\text { of scores }\end{array}$ & $\begin{array}{c}\text { Change in the } \\
\text { number of scores }\end{array}$ \\
\hline 14 & Lithuania & 80.83 & +0.29 \\
\hline 19 & Latvia & 79.59 & +0.33 \\
\hline 33 & Poland & 76.95 & -0.07 \\
\hline 35 & Czech Republic & 76.10 & +0.05 \\
\hline 52 & Romania & 72.30 & -0.53 \\
\hline 59 & Bulgaria & 71.24 & +0.11 \\
\hline 71 & Ukraine & 68.25 & +0.94 \\
\hline
\end{tabular}

particular, the attitude towards relations with Russia and state power, the focus on political and economic reforms, support for local autonomy or centralization, and, finally, integration with the EU. The source of regional differences (especially between East and West) is the historical experience, economic structure, ethnic composition, connection with border states and language. Polls conducted among Ukrainians before the armed conflict with the Russian Federation showed that $90 \%$ of the population in the west of the country, $70 \%$ in the center and only $29 \%$ in the south and $20 \%$ in the east supported integration with the EU [10].

This fact shows that political factors that affect the possibility of change in the institutional environment are extremely important. The main one is the country's ability to ensure political stability for investors. Therefore, the government, which seeks to attract investment in vital sectors of economy, should pay special attention to political institutions and, if necessary, design mechanisms to compensate for institutional shortcomings [11, 12]. At the same time, investors not only demand the appropriate institutional environment, but should also trust any explicit or implicit promises of the government, which are indicators of the possibility of obtaining a fair rate of return on investment.

This is confirmed by the annual reports of the World Economic Forum on the global competitiveness of countries, which assess the economic environment of the countries of the world and their ability to achieve sustainable economic growth. The following, which is defined as twelve pillars of competitiveness, is assessed: institutions, infrastructure, macroeconomic stability, health care and primary education, higher education and training, commodity market efficiency, labor market efficiency, financial markets development, market sizes, advanced business environment, innovation [5]. At the same time, the Report identifies the following institutions: property rights, intellectual property rights, embezzlement of public funds, illegal payments and bribes, public trust in politicians, independence of the judiciary, favoritism in government decisions, inefficiency of state expenditures, the burden of state regulation, the effectiveness of the legal environment, transparency of public policy, costs of terrorism for business, costs of business due to crime and violence, organized crime, reliability of police services, corporate ethics, ethical conduct of firms, reliability of auditing and reporting standards, efficiency of work of corporate boards of directors, protection of interests of minority shareholders, reliability of protection of investors. Among the most problematic factors affecting Ukraine's economy, experts noted the institutional ones.

Conclusions. Thus, for successful economic growth of Ukraine and its prospects for European integration, the transformation of the institutional environment should go on in accordance with European standards. In its turn, the quality of the institutional environment is determined by the efficiency of key institutions. Although the impact of institutions on eco- 
nomic performance is indirect, since institutions do not directly produce goods or services, at the same time, the amount and productivity of resources depend on the quality of the institutional environment of the country. The importance of the institutional environment for economic development is also related to its main functions: reducing uncertainty by limiting possible behaviors of firms and households, reducing transaction costs and creating a stable environment for the interaction of economic agents. However, we have reasonable doubts as to whether Ukraine has the necessary institutional environment to stimulate innovation, ensure sustainable economic growth and competitiveness, which will ultimately provide the foundation for the country's European integration aspirations. One should admit that the system of education in Ukraine does not take into account current challenges the state is faced with. The most influential challenges are the epidemic of coronavirus and military aggression, as well as the need for training specialists able to satisfy the needs of labour market in the long-term perspective with an emphasis on the development of innovative sectors of economy. The way out of the economic crisis is possible only when reforming the system of education in the context of the institutional improvement of the state policy in the sphere of innovative development of Ukraine. It involves changing approaches to forming state requirements in accordance with long-term economic strategy of the state and career opportunities of the graduates; changing licensing systems for vocational and higher educational institutions; development of the concept of dual education, introduction of a functioning labour market monitoring; introduction of a career card in specialties for graduates of educational institutions and modernization of the concept of lifelong learning.

Thus, the reform of Ukrainian education, taking into account the studied European integration trends and transformation processes in the socio-economic and educational spheres of Ukraine, involves radical changes in the content, forms of organization and methods of teaching and education. That means designing of the educational process as an institution of successful personal and professional socialization based on the requirements of the EU. This will ensure the growth of socio-economic potential of the state and will lead to the growth of national capital through the accelerated accumulation of human one, which will bring Ukraine closer to fullfledged European integration. Only in this case, reformed education will be a prerequisite for quality training of highly qualified competitive professionals and will achieve sustainable economic growth in Ukraine, which will be able to meet internal and external challenges such as a global pandemic or Russian aggression.

\section{References.}

1. Velychko, O., \& Velychko, L. (2018). Matrix structures in management of quality of educational and scientific work of Ukrainian universities. Problems and Perspectives in Management, 16(1), 133-144. https://doi.org/10.21511/ ppm.16(1).2018.13.

2. Nitsenko, V., Havrysh, V., \& Zakharchenko, O. (2018). Model for optimizing the network of higher education institutions in Ukraine. Actual problems of innovative economy, 1, 31-44.

3. Burlay, T. V. (2019). Factors of the socio-economic divergence between Ukraine and the European Union. Ukrainian Society, 2(69), 61-83. https://doi.org/10.15407/socium2019.02.061.

4. Ukrstat.org - State Statistics Service of Ukraine documents publishing. Demographic and social statistics/Education (n.d.). Retrieved from https://ukrstat.org/en/operativ/menu/ menu e/osv.htm.

5. Schwab, K. (2019). The Global Competitiveness Report. Geneva: Economic Forum. Retrieved from http://www3.weforum. org/docs/WEF_TheGlobalCompetitivenessReport2019.pdf.

6. Reinert, E. (2017). Do not do what the Americans tell you, but do what the Americans did themselves. Mirror of the week, 8,4. Retrieved from https://zn.ua/ukr/business/erik-raynert- ne-robit-te-scho-vam-kazhut-robiti-amerikanci-a-robit-tescho-amerikanci-robili-sami-html.

7. Bilan, Y., Zos-Kior, M., Nitsenko, V., Sinelnikau, U., \& Ilin, V. (2017). Social component in sustainable management of land resources. Journal of Security and Sustainability Issues, 7(2), 107-120. https://doi.org/10.9770/issi.2017.7.2(9).

8. Geneva: World Intellectual Property Organization. World Intellectual Property Indicators 2017 (2018). Retrieved from https://www.wipo.int/edocs/pubdocs/en/wipo_pub_941_2018. pdf.

9. Washington: International Bank for Reconstruction and Development (2018). Doing Business 2019. https://doi. org/10.1596/978-1-4648-1326-9.

10. Lewandowska, A., \& Inglot-Brzek, E. (2015). European Integration of Ukraine: the Perspective of Ukrainians and Poles. Barometr Regionalny, 3(41), 17-24.

11. Lammam, Ch., Palacios, M., Ren, F., \& Clemens, J. (2015). Comparing Government and Private Sector Compensation in Canada. Fraser Institute. Retrieved from https://www. fraserinstitute.org/sites/default/files/comparing-governmentand-private-sector-compensation-in-canada.pdf.

12. Kholiavko, N., Popova, L., Marych, M., Hanzhurenko, I., Koliadenko, S., \& Nitsenko, V. (2020). Comprehensive methodological approach to estimating the research component influence on the information economy development. Naukovyi Visnyk Natsionalnoho Hirnychoho Universytetu, (4), 192199. https://doi.org/10.33271/nvngu/2020-4/192.

\section{Інституційні та соціально-економічні чинники освітнього тренду в Україні в контексті євроінтеграції}

\section{О. В. Куклін ${ }^{1}$, Р. Ф. Пустовійт ${ }^{1}$, Н.А. Азьмук ${ }^{1}$ B. I. Гунько ${ }^{2}$, Н. I. Моісєєва}

1 - Черкаський державний бізнес-коледж, м. Черкаси, Україна, e-mail: rfpustovit@gmail.com

2 - Черкаська гімназія № 9, м. Черкаси, Україна

3 - Харківський національний технічний університет сільського господарства імені Петра Василенка, м. Харків, Україна

Мета. Оцінка інституційних чинників і результати реформування освіти України, з урахуванням економічного й соціального розвитку країни; конкретизація основних інституційних євроінтеграційних тенденцій України в галузі освіти з урахуванням чинника людського капіталу.

Методика. Методологічною основою пропонованої роботи є такі універсальні методи наукового пізнання як: аналіз; синтез; індуктивний метод; дедуктивний метод; причинно-наслідкове моделювання; комплексне застосування взаємодоповнюючих підходів і методів на підгрунті принципів загальнонаукової методології, зокрема, компетентнісний, особистісно-орієнтований, культурологічний.

Результати. Встановлено, що умови реформування української освіти, з урахуванням досліджуваного глобального освітнього тренда та євроінтеграційних тенденцій, передбачають відповідні інституційні процеси в соціально-економічній сфері й кардинальні зміни змісту, форм організації та методів навчання й виховання. Тобто, мова йде про проектування освітнього процесу як інституту успішної особистісної та професійної соціалізації на основі вимог $\mathrm{CC}$, що призведе до зростання загальнодержавного капіталу шляхом прискореного накопичення людського й наблизить Україну до повноцінної євроінтеграції.

Наукова новизна. Упродовж дослідження визначені ключові тенденції в українській, європейській і світовій 
освітніх сферах, а також виявлені причини, що негативно впливають на розвиток освіти України та не дозволяють у значній мірі впливати на конкурентний потенціал країн і реалізувати євроінтеграційні можливості. На відміну від раніше запропонованих досліджень, даний підхід акцентує увагу на інституційних і соціально-економічних факторах освітнього тренда.

Практична значимість. Результати досліджень, можуть бути використані фахівцями при формуванні інституційних затребувань до проектування тренда освітньої системи України з урахуванням вимог євроінтеграції.

Ключові слова: інституціональна економіка, освітній процес, людський капітал, євроінтеграція

\section{Институциональные и социально- экономические факторы образовательного тренда в Украине в контексте евроинтеграции}

О. В. Куклин ${ }^{1}$, Р. Ф. Пустовийт ${ }^{1}$, Н. А. Азьмук ${ }^{1}$, В. И. Гунько ${ }^{2}$ Н. И. Моисеева ${ }^{3}$

1 - Черкасский государственный бизнес-колледж, г. Черкассы, Украина, e-mail: rfpustovit@gmail.com 2 - Черкасская гимназия № 9, г. Черкассы, Украина 3 - Харьковский национальный технический университет сельского хозяйства имени Петра Василенко, г. Харьков, Украина

Цель. Оценка институциональных факторов и результатов реформирования образования Украины, с учетом экономического и социального развития страны; конкретизация основных институциональных евроинтеграционных тенденций Украины в сфере образования с учетом фактора человеческого капитала.

Методика. Методологической основой предлагаемой работы являюся такие универсальные методы научного познания как: анализ; синтез; индуктивный метод; де- дуктивный метод; причинно-следственное моделирование; комплексное применение взаимодополняющих подходов и методов на основе принципов общенаучной методологии, в частности, компетентностный, личностно-ориентированный, культурологический.

Результаты. Установлено, что условия реформирования украинского образования, с учетом исследуемого глобального образовательного тренда и евроинтеграционных тенденций, предусматривают трансформационные институциональные процессы в социально-экономической сфере и кардинальные изменения содержания, форм организации и методов обучения и воспитания. То есть, речь идет о проектировании образовательного процесса как института успешной личностной и профессиональной социализации на основе требования ЕС, что приведет к росту общегосударственного капитала путем ускоренного накопления человеческого и приблизит Украину к полноценной евроинтеграции.

Научная новизна. В ходе исследования определены ключевые тенденции в украинской, европейской и мировой образовательных сферах, а также выявлены причины, которые негативно влияют на развитие образования Украины и не позволяют в полной мере влиять на конкурентный потенциал стран и реализовать евроинтеграционные возможности. В отличие от ранее предлагаемых исследований, данный подход акцентирует внимание на институциональных и социально-экономических факторах образовательного тренда.

Практическая значимость. Результаты исследований, могут быть использованы специалистами при формировании институциональных требований к проектированию тренда образовательной системы Украины с учетом требований евроинтеграции.

Ключевые слова: институциональная экономика, образовательный процесс, человеческий капитал, евроинтеграция

Recommended for publication by L. O. Petkova, Doctor of Economic Sciences. The manuscript was submitted 14.06.20. 